The Digital Object Identifier - DOI: 10.37952/ROI-jbc-01/20-61-2-108

Submitted on February 15, 2020.

\title{
Methods for modeling the kinetics of radiopharmaceuticals with iodine isotopes in nuclear medicine problems
}

\author{
(C) Alexander V. Matveev \\ Department of Applied and Medical Physics. Dostoevsky Omsk State University. \\ Mira St., 55A.Omsk, 644077. Russia.Phone:+7 (3812)22-28-39.E-mail:matav@mail.ru
}

Keywords: radiopharmaceutical, pharmacokinetics, modeling, iodine, nuclear medicine.

\begin{abstract}
The paper considers modeling methods and develops a unified approach to the construction of mathematical models of the kinetics of radiopharmaceuticals with iodine isotopes in the human body during diagnostic and therapeutic procedures of nuclear medicine. Based on this approach, three- and fourcompartment pharmacokinetic models were developed and corresponding calculation programs were created in the $\mathrm{C}++$ programming language for processing and evaluating the results of radionuclide diagnostics and therapy. Various methods for identifying model parameters based on quantitative data from radionuclide studies of the functional state of vital organs are proposed. The results of pharmacokinetic modeling for radionuclide diagnostics of the liver, kidney, and thyroid using iodine-containing radiopharmaceuticals are presented and analyzed.

Using clinical and diagnostic data, individual pharmacokinetic parameters of transport of different radiopharmaceuticals in the body (transport constants, half-life periods, maximum activity in the organ and the time of its achievement) were determined. It is shown that the pharmacokinetic characteristics for each patient are strictly individual and cannot be described by averaged kinetic parameters.

Within the framework of three pharmacokinetic models, "Activity-time" relationships were obtained and analyzed for different organs and tissues, including for tissues in which the activity of a radiopharmaceutical is impossible or difficult to measure by clinical methods. Also discussed are the features and the results of simulation and dosimetric planning of radioiodine therapy of the thyroid gland. It is shown that the values of absorbed radiation doses are very sensitive to the kinetic parameters of the compartment model. Therefore, special attention should be paid to obtaining accurate quantitative data from ultrasound and thyroid radiometry and identifying simulation parameters based on them.

The work is based on the principles and methods of pharmacokinetics. For the numerical solution of systems of differential equations of the pharmacokinetic models we used Runge-Kutta methods and Rosenbrock method. The Hooke-Jeeves method was used to find the minimum of a function of several variables when identifying modeling parameters.
\end{abstract}

\section{References}

[1] N.R. Kar. Production and Applications of Radiopharmaceuticals: A Review. International Journal of Pharmaceutical Investigation. 2019. Vol.9. No.2. P.36-42. DOI: 10.5330/ijpi.2019.2.8

[2] F.B. Payolla, A.C. Massabni, C. Orvig. Radiopharmaceuticals for diagnosis in nuclear medicine: a short review. Eclética Química Journal. 2019. Vol.44. No.3. P.11-19. DOI: 10.26850/16784618eqj.v44.3.2019.p11-19

[3] S. Debnath, M.N. Babu, G.V. Kumar. Radiopharmaceuticals and their Therapeutic Applications in Health Care System. Pharma Times. 2016. Vol.48. No.3. P.15-18. DOI: 10.5958/2231-5659.2015.00032.6

[4] S.K. Zyryanov, K.E. Zatolochina. Prospects for the use of radionuclide drugs in the treatment of malignant neoplasms in the Russian Federation. Kachestvennaya klinicheskaya praktika. 2018. No.2. P.51-57. (russian).

[5] V.I. Chernov, A.A. Medvedev, I.G. Sinilkin, R.V. Zelchan, O.D. Bragina, E.L. Choynzonov. Nuclear medicine as a tool for diagnosis and targeted cancer therapy. Bulletin of Siberian Medicine. 2018. Vol.17. No.1. P.220-231. DOI: 10.20538/1682-0363-2018-1-220-231

[6] A.V. Matveev. Nuclear medicine: radioisotopes and pharmaceuticals. Omsk: OmSU. 2016. 128p. (russian)

[7] A.F. Cyb, A.V. Dreval', P.I. Garbuzov et al. Radioiodine therapy of thyrotoxicosis: a guide. Moscow: GEOTAR-Media. 2009. 160p. (russian)

[8] Radionuclide diagnostics for practitioners. Ed. by Lishmanov Yu.B., Chernov V.I. Tomsk: STT. 2004. 394p. (russian) 
[9] O.G. Sinyakova. Methods of mathematical modeling for estimation of the organism condition (radionuclide diagnostics). Automation and Remote Control. 2005. Vol.66. P.129-138. DOI: 10.1007/s10513-005-0013-5

[10] V.I. Sergienko, R. Dzhelliff, I.B. Bondareva. Applied pharmacokinetics: main provisions and clinical application. Moscow: Izd-vo RAMN. 2003. 208p. (russian)

[11] I.B. Bondareva. Mathematical modeling in pharmacokinetics and pharmacodynamics: Dis. ... Dr. of Biol. Sciences. Moscow. 2001. 373p. (russian)

[12] M.P. Galanin, S.R. Hodzhaeva. Development and testing of methods for solving hard ordinary differential equations. Mathematical Modeling and Computational Methods. 2014. No.4. P.95-119. (russian)

[13] N.N. Kalitkin, P.V. Koryakin. Numerical methods: in 2 books. Book 2. Methods of mathematical physics: textbook for university students. Moscow: Akademiya. 2013. 304p. (russian)

[14] V.D. Sulimov, P.M. Shkapov, S.K. Nosachev. Local search using the Hooke-Jeeves method in a hybrid global optimization algorithm. Science and Education: Scientific Publication of Bauman MGTU. 2014. No.6. P.107-123. (russian)

[15] R. Hooke, T.A. Jeeves. Direct search for solutions to numerical and statistical problems. Moscow: Mir. 1961. 219p. (russian)

[16] W. Aljubeh, A. Shaheen, O. Zalloum. Radioiodine I-131 for Diagnosing and Treatment of Thyroid Diseases. Conference Paper. 2012. No.6. URL: https://www.researchgate.net/publication/295919808

[17] J. Tang, D. Kong, Q. Cui, K. Wang, D. Zhang, X. Liao, Y. Gong, G. Wu. The role of radioactive iodine therapy in papillary thyroid cancer: an observational study based on SEER. OncoTargets and Therapy. 2018. Vol.11. P.3551-3560. DOI: 10.2147/OTT.S160752

[18] A.V. Matveev, D.Yu. Noskovec. Pharmacokinetic modeling and dosimetric planning of radioiodine therapy of thyrotoxicosis. Herald of Omsk University. 2014. No.4. P.57-64. (russian).

[19] A.V. Matveev, D.Yu. Noskovec. Features of dosimetric planning of radioiodine therapy on the basis of pharmacokinetic modeling. Herald of Omsk University. 2016. No.3. P.74-83. (russian)

[20] O.P. Vlasova, A.N. Klepov, E.S. Matusevich, E.P. Poculko. Mathematical modeling for dosimetric planning of radioiodotherapy for patients with thyroid diseases. Journal of New Medical Technologies. 2008. Vol.15. No.1. P.17-19. (russian)

[21] N.N. Lipanova, A.N. Klepov, B.Ya. Narkevich. Treatment Planning and Dose Monitoring for Radioiodine Therapy of Thyroid Cancer. Medical Radiology and Radiation Safety. 2012. Vol.57. No.3. P.53-65. (russian)

[22] N.N. Lipanova. Radiobiological and dosimetric substantiation of radionuclide therapy of thyroid diseases: Dis. ... Cand. of Phys.-Mat. Sciences. Moscow. 2012. 115p. (russian)

[23] O.P. Vlasova. Method of identification of parameters of radioiodine metabolism and calculation of absorbed doses in radionuclide therapy of the thyroid gland: Dis. ... Cand. of Biol. Sciences. Moscow. 2010. 124p. (russian)

[24] D.S. Lizogub, A.V. Matveev. Radioisotope methods of investigation in the diagnosis of diseases of the thyroid gland. Collection of Scientific Articles "Youth of the Third Millennium". Omsk: OmSU. 2017. P.701-706. (russian). URL: https://omsu.ru/science/materialy-konferentsiy/2017/M-III_2017.pdf

[25] D.S. Lizogub, A.V. Matveev. Individual dosimetric planning of radioiodine therapy based on compartmental modeling. Problemy nauchnoj mysli. 2019. Vol.7. No.3. P.15-17. (russian)

[26] E.B. Silberstein. Comparison of Outcomes After ${ }^{123}$ I Versus ${ }^{131}$ I Preablation Imaging Before Radioiodine Ablation in Differentiated Thyroid Carcinoma. Journal of Nuclear Medicine. 2007. Vol.48. No.7. P.10431046. DOI: 10.2967/jnumed.107.040311

[27] A.V. Matveev. Pharmacokinetic model and calculation of absorbed doses in radionuclide therapy of thyroid cancer. Diagnostic radiology and radiotherapy. 2019. Vol.10. No.4. P.80-86.DOI: 10.22328/2079-5343-2019-10-4-80-86

[28] V.K. Polenko, P.S. Ponomarev, V.A. Chibisov et al. Radioisotope diagnostics. Moscow: Voenizdat. 1984. 128p. (russian)

[29] A.V. Matveev, M.Yu. Korneeva. Features of modeling of kinetics of radiopharmaceuticals in functional research of the gepatobiliarny system. Herald of Omsk University. 2015. No.3. P.42-51. (russian)

[30] V.Yu. Kundin, S.V. Pospelov. Radiopharmaceuticals for visualization and evaluation of the functional state of the urinary system. Urologiya. Ukrains'kij naukovo-praktichnij zhurnal urologiv, andrologiv ta nefrologiv. 2012. Vol.16. No.2. P.58-64.

[31] N.A. Lopatkin, A.G. Pugachev. Vesicoureteral reflux. Moscow: Medicina. 1990. 208p. (russian)

[32] A.V. Matveev. Features of modeling of kinetics of radiopharmaceuticals in functional research of the urinary system. Herald of Omsk University. 2019. No.3. P.58-68. DOI: 10.25513/18123996.2019.24(3).58-68 